\title{
Non-teratoid ocular medulloepithelioma in an adult horse
}

\author{
Mariana Oliveira Silva ${ }^{1 *}\left(\right.$ Leonardo Costa Tavares Coelho ${ }^{2}([)$ \\ Adriane Pereira Vidal ${ }^{3}\left(\right.$ Cíntia Alves Teixeira $^{3}$ Gustavo Henrique Siqueira Ribeiro $^{3}$ (으 \\ Natália Cristina de Melo $^{3}$ () Priscila Fantini ${ }^{2}$ (1)
}

${ }^{1}$ Programa de Residência Integrada em Medicina Veterinária, Universidade Federal de Minas Gerais (UFMG), 31270-901, Belo Horizonte, MG, Brasil. E-mail: marianaolive.vet@gmail.com *Corresponding author.

${ }^{2}$ Departamento de Grandes Animais, Centro Universitário Una Bom Despacho, Bom Despacho, MG, Brasil.

${ }^{3}$ Curso de Medicina Veterinária, Centro Universitário Una Bom Despacho, Bom Despacho, MG, Brasil.

ABSTRACT: This is a case of medulloepithelioma in a 14-year-old mixed breed gelding horse, presenting a large abnormal mass of tissue involving the entire extension of the right eye. Ophthalmic examination showed deformation and swelling of the eye. The animal showed signs of pain on palpation of the organ, but the specific examination of the systems did not reveal any other changes. Due to the extension of the apparently neoplastic mass and the discomfort experienced by the animal, transpalpebral enucleation procedure was decided. The excised tissue was sent for histopathological analysis, wherein a neoplastic proliferation of neuroectodermal cells was noted. The neoplasm was poorly delimited, unencapsulated, infiltrative, sustained by moderate fibrovascular stroma, and formed cords and rosettes with cells arranged in palisades around the luminal structures (Flexner-Wintersteiner rosettes), suggestive of medulloepithelioma. The immunohistochemical profile was also performed, confirming the diagnosis. The neoplastic cells were immunolabeled to vimentin, S100 protein (S100), and specific neuro enolase (NSE), but not for pan cytokeratin (AE1AE3), glial fibrillary acidic protein (GFAP), and cytokeratin 8/18 (CK8/18). Five months postoperatively, the animal was healthy, without any relapse or evidence of metastasis.

Key words: ocular neoplasia, tumor, histopathology.

Meduloepitelioma ocular não-teratóide em um equino adulto

RESUMO: Esse é um caso de meduloepitelioma em um equino sem raça definida, castrado, de 14 anos de idade, que chegou ao atendimento apresentando grande massa de tecido envolvendo toda a extensão do olho direito. No exame oftálmico, foi observada deformação e aumento de volume ocular. $O$ animal manifestou sinais de dor na palpação do órgão, mas o exame específico dos sistemas não revelou demais alterações. Devido à extensão da massa aparentemente neoplásica e o desconforto experimentado pelo equino foi decidida a realização da enucleação transpalpebral. O tecido excisado foi enviado para exame histopatológico, no qual observou-se proliferação neoplásica de células neuroectodérmicas, de forma mal delimitada, não encapsulada, infiltrativa, sustentada por estroma fibrovascular moderado, e formação de cordões e rosetas, com células dispostas em paliçadas ao redor de estruturas luminais (rosetas de Flexner-Wintersteiner), sugestivo de meduloepitelioma. O perfil imunohistoquímico também foi realizado, confirmando o diagnóstico. As células neoplásicas foram imunomarcadas para vimentina, proteina S100 (S100) e neuro enolase especifica (NSE), mas não para pan citoqueratina (AE1AE3), proteina glial fibrilar ácida (GFAP) e citoqueratina 8/18 (CK8 / 18). Após cinco meses da realização do procedimento cirúrgico o animal apresentava-se saudável, sem recidiva ou evidência de metástase.

Palavras-chave: neoplasia ocular, tumor, histopatologia.

Medulloepithelioma is an intraocular neoplasia arising from embryonic neural tissue (LOUIS et al., 2007). This type of tumor occurs unilaterally, may be congenital or acquired, develops mainly from the non-pigmented ciliary epithelium, and rarely affects the optic nerve or retina (KLOSTERMAN et al., 2006; MONK et al., 2016).
It is a rare tumor with slow growth, and; although, locally aggressive, metastases to distant sites are uncommon (CANNING et al., 1988; POPE et al., 2002). Medulloepitheliomas have been described most frequently in humans, with few reports in other species such as in dogs (WILCOCK \& WILLIAMS, 1980; ALEKSANDERSEN et al., 2004), cats (JELINEK et 
al., 1996), llamas (SCHOENIGER et al., 2006), and horses (EAGLE et al., 1978; SZYMANSKI, 1987; RIIS et al., 1990; UEDA et al., 1993). It occurs in young animals in most species (ALEKSANDERSEN et al., 2004), but in horses is more commonly observed in adults (HOLLINGSWORTH, 2011). Because of its cell differentiation capacity, medulloepitheliomas can be classified as non-teratoids or teratoids, and benign or malignant. Non-teratoid medulloepitheliomas are composed of undifferentiated neuroepithelial cells, while teratoid medulloepitheliomas contain heteroplastic components, such as cartilage, muscle fibers, and neuronal tissue (MONK et al., 2016). Due to the limited number of case reports on this condition, the present study aimed to describe the clinical and pathological findings of medulloepithelioma in an adult horse.

A 14-year-old gelding horse of mixed breed, weighing approximately $400 \mathrm{~kg}$, presented a large abnormal mass in the right eye with bloody and mucopurulent content, which was sent to the Large Animals Clinic of the UNA Bom Despacho educational institution (Figure 1a). The animal carried out transport activities on the farm where it lived, and the owner reported that he noticed an increase in size in the affected eye two months ago. Since then, the condition had worsened according to him. In the general physical examination, the animal was alert with all vital signs within the reference range, but the large mass in the eye bothered the animal and caused pain on palpation.
The ophthalmological inspection showed deformation and swelling of the eyeball caused by advanced neoplasia. The intraocular pressure was not gauged, but the increase in volume and firm consistency of the eye on palpation indicated glaucoma associated with neoplasia due to the impaired drainage of ocular fluids. Because of the intense inflammation at the time of examination, it was not possible to distinguish the ocular structures. The animal had complete loss of vision in the affected eye. Other specific tests, including neurological tests, showed no significant results.

Based on the clinical and ophthalmic examinations, the procedure of transpalpebral enucleation of the right eye was decided. The preparation of the animal consisted of four hours of a water fast and eight hours of a food fast. The procedure went well without any significant complications, and the animal was sent to the hospital for recovery. Postoperatively, the animal was treated with anti-inflammatory drugs for five days. Until complete cicatrization, the enucleation region was cleaned daily.

The enucleated eyeball measured 11,5 $\times 11 \times 8.5 \mathrm{~cm}$ and it was firm, red to pink with a fleshy aspect (Figure 1b). There was no neoplastic involvement of the eyelids, but local invasion was found in the conjunctiva. Postoperatively, the excised eyeball was fixed intact in $10 \%$ neutral buffered formalin for 24 hours, sectioned in the dorsoventral plane by a veterinarian, and a sample was sent to the laboratory for histopathological analysis. Grossly, the

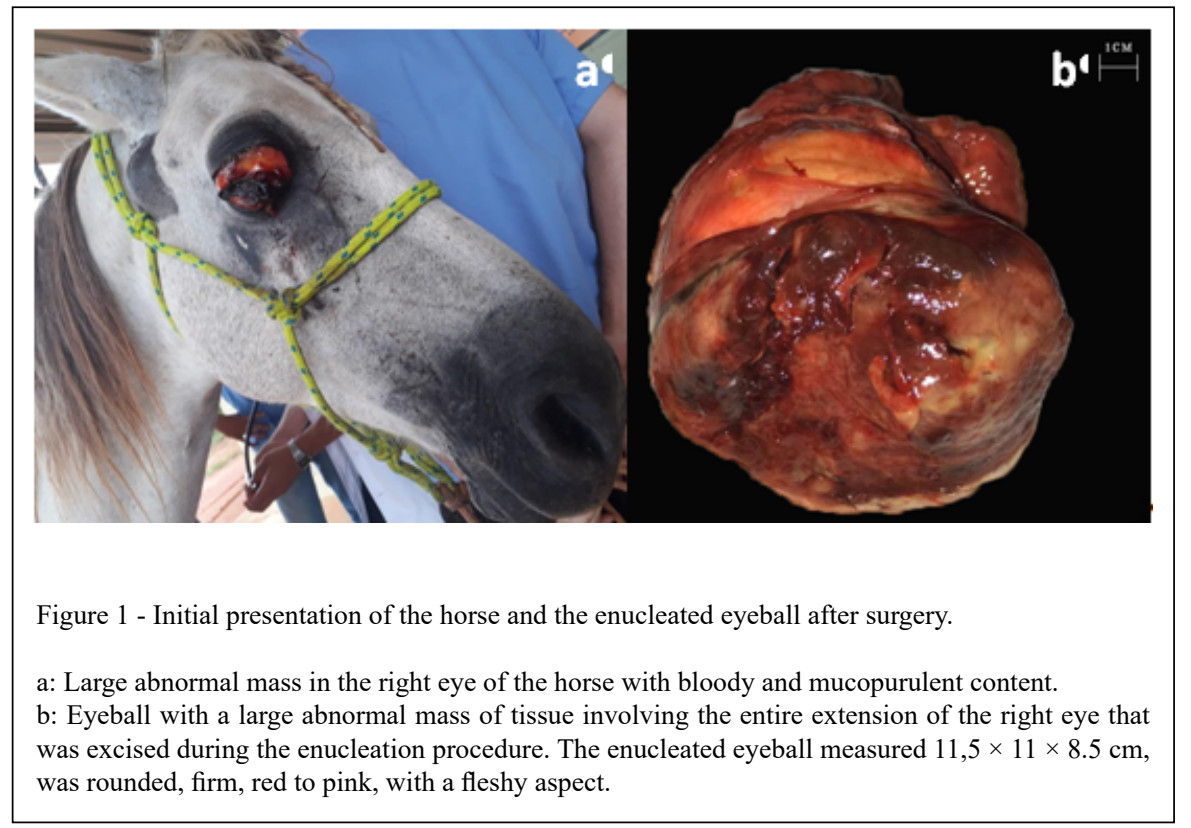

Ciência Rural, v.51, n.4, 2021. 
fragment measured $1.0 \times 2.5 \times 1.2 \mathrm{~cm}$, with an irregular, whitish, and soft surface. The histopathological analysis revealed that the fragment contained a neoplastic proliferation of neuroectodermal cells embedded within well-arranged connective tissue and aside to a fragment of skeletal muscle. The neuroectodermal cells were poorly delimited, unencapsulated, infiltrative, supported by moderate fibrovascular stroma, and forming cords and rosettes with palisades cells arranged around the luminal structures (Flexner-Wintersteiner rosettes) (Figure 2). The neoplastic cells obtained were primitive and juxtaposed with less-defined cytoplasmic limits, showing scarce and eosinophilic cytoplasm. Cellular and smooth nuclear pleomorphism and seven mitoses in 10 higher magnification fields (400x) were reported.

The absence of tissues not found naturally in the eye (e.g., cartilage, brain tissue) categorized the neoplasm as non-teratoid. Even though this type is commonly classified as malignant, the prognosis is favorable, and; although, locally aggressive, it rarely metastasizes to regional lymph nodes and lungs (EAGLE et al., 1978).

According to DUBIELZIG et al. (2010), the main histological characteristic of medulloepithelioma is the formation of rosettes. The Flexner-Wintersteiner rosettes reported in the histopathological examination of this sample have been reported in other primitive neuroectodermal tumors and retinoblastomas, hence that feature is not specific to medulloepitheliomas. The specific rosettes for this type of tumor are larger and more complex, with multi-layered or tubular structures of neuroblastic columnar cell lining. Therefore, immunohistochemistry was; subsequently, performed to confirm the suspicion of medulloepithelioma and exclude the differential diagnoses.

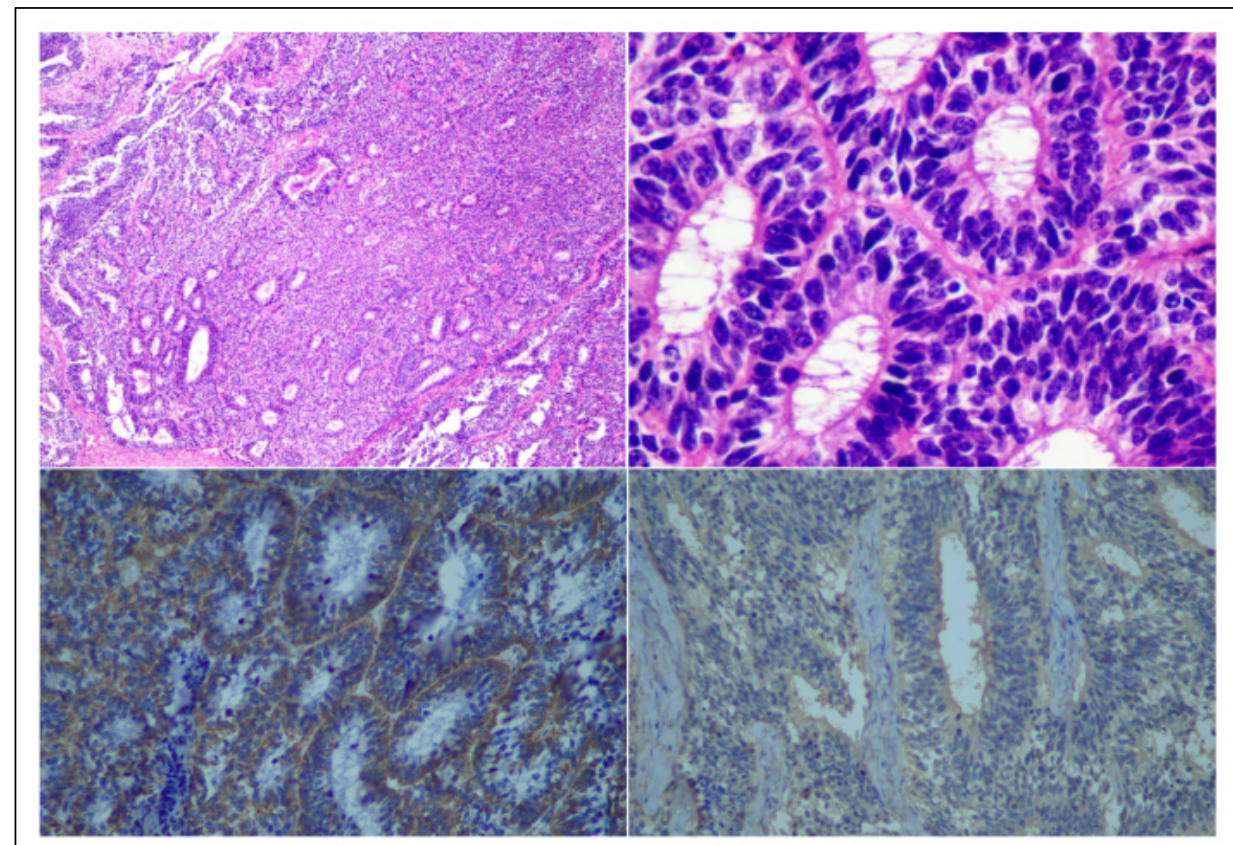

Figure 2 - Histological appearance with hematoxylin and eosin staining, and with staining effects of immunohistochemistry (IHC).

a: Neoplastic proliferation is evidenced in smaller magnification during histopathological analysis. Hematoxylin \& Eosin staining. 40x.

b: Neoplastic proliferation forming cords and rosettes is observed with cells arranged in palisades around the luminal structures (Flexner-Wintersteiner rosettes) during histopathological analysis. Hematoxylin \& Eosin staining.400x.

c: Neoplastic cells, immunolabeling for vimentin, exhibit introplasmatic and diffuse marking pattern. IHC. 40x.

d: Neoplastic cells, immunolabeling for specific neuro enolase (NSE), exhibit introplasmatic and diffuse marking pattern. IHC. 40x. 
Previous immunohistochemical studies showed that neoplastic cells were positive for vimentin, S-100 protein, neuron-specific enolase (NSE), and nestin and negative for glial fibrillary acidic protein (GFAP) (LEIVA, 2013). The immunohistochemical profile performed confirmed the medulloepithelioma diagnosis. The neoplastic cells were immunolabeled to vimentin, S100 protein (S100), and specific neuro enolase (NSE), but not for pan cytokeratin (AE1AE3), glial fibrillary acidic protein (GFAP), and cytokeratin 8/18 (CK8/18) (Figure 2c and Figure 2d).

There are several differential diagnoses of medulloepithelioma, of which retinoblast is the most important. This is because both tumors are primary intraocular primitive neuroectodermal tumors derived from the primitive medullary epithelium and have similar histopathological features (BALMER et al., 2006; KNOTTENBELT et al., 2007). The greatest similarity is in the formation of the FlexnerWintersteiner rosettes, which is a characteristic histological characteristic of well-differentiated retinoblastoma, but they were also observed in medulloepitheliomas with a higher degree of differentiation (FONT et al., 2006; LOUIS et al., 2007). Other differential diagnoses were associated with primary intraocular neuroepithelial tumors that are derived from the mature epithelium (adenomas and adenocarcinomas). These share a common phenotype and originate from the optic cup neuroectoderm, similarly to medulloepitheliomas (KLOSTERMAN et al., 2006). Hence, a final diagnosis cannot be obtained based only on the morphological findings, and diagnostic confirmation depends on the immunohistochemistry and electron microscopic results, which helps in distinguishing the tumor (KNOTTENBELT et al., 2007).

With respect to the diagnosis based on the histopathological and immunohistochemistry results of this case, the enucleation or exenteration procedure was recommended, because some previous reports of medulloepithelioma in horses showed that the tumor had propagated (EAGLE; 1978; BISTNER et al., 1983; KNOTTENBELT et al., 2007).

It was concluded that; although rare, medulloepithelioma still affects horses, and the knowledge of this neoplasia is important in equine clinics. Histopathology along with immunohistochemistry showed good results as a diagnostic method, clearly distinguishing the condition. The surgical approach of enucleation of the affected eye was the appropriate choice, because the animal's recovery was fast and the treatment was effective, which ensured a satisfactory postoperative quality of life for the horse, that, after five months was healthy, without any relapse or evidence of metastasis.

\section{ACKNOWLEDGEMENTS}

We would like to thank Editage (www.editage.com) for English language editing.

\section{BIOETHICS AND \\ COMMITTEE APPROVAL}

BIOSSECURITY

The authors of this article declare that the project that gave rise to the present data has not been submitted for evaluation to the Ethics Committee of the Centro Universitário UNA Bom Despacho (UNA). However, we are aware of the content of the Brazilian resolutions of the National Council for Control of Animal Experimentation (CONCEA) http://www.mct.gov. br/index.php/content/view/310553.html regarding involvement of animals. Thus, the authors assume full responsibility for the presented data and are available for possible questions, if required by the competent authorities.

\section{DECLARATION OF CONFLICT OF INTERESTS}

The authors declare no conflict of interest. The founding sponsors had no role in the design of the study; in the collection, analyses, or interpretation of data; in the writing of the manuscript, and in the decision to publish the results.

\section{AUTHOR'S CONTRIBUTIONS}

All authors contributed equally for the conception and writing of the manuscript. All authors critically revised the manuscript and approved of the final version.

\section{REFERENCES}

ALEKSANDERSEN, M. et al. Malignant teratoid medulloepithelioma with brain and kidney involvement in a dog. Veterinary Ophthalmology, v.7, n.6, p.407-411, 2004. Available from: $<$ https://doi.org/10.1111/j.1463-5224.2004.04054. $\mathrm{x}>$. Accessed: Jun. 22, 2019. doi: 10.1111/j.14635224.2004.04054.x.

BALMER, A. et al. Diagnosis and current management of Retinoblastoma. Oncogene, v. 25, n.38, p.5341-534, 2006. Available from: <https://www.researchgate.net/ publication/6851377_Diagnosis_and_current_management of retinoblastoma $>$. Accessed: May, 23,2020 . doi: 10.1038/ sj.onc. 1209622 .

BISTNER, S. et al. Neuroepithelial tumor of the optic nerve in a horse. The Cornell Veterinarian, v.73, n.1, p.30-50, 1983. Available from: <https://pubmed.ncbi.nlm.nih.gov/6825451/>. Accessed: May, 23, 2020. PMID: 6825451.

CANNING, C. R. et al. Medulloepithelioma (diktyoma). British Journal of Ophthalmology, v.72, p.764-767, 1988. Available from: $<$ https://www.ncbi.nlm.nih.gov/pmc/articles/PMC1041579/>. Accessed: Jun. 22, 2019. doi: 10.1136/bjo.72.10.764. 
DUBIELZIG, R. R. et al. Veterinary Ocular Pathology: A comparative review. New York: Saunders Elsevier, 2010. 2v.

EAGLE, R. C. et al. Malignant medulloepithelioma of the optic nerve in a horse. Veterinary Pathology, v.15, n.4, p.488-494, 1978. Available from: <https://www.ncbi.nlm.nih.gov/pubmed/695223>. Accessed: Jun. 22, 2019. doi: 10.1177/030098587801500406.

FONT, M. D. et al. Afip Atlas of Tumor Pathology, Series 4/05. Washington DC: American Registry of Pathology (ARP), Armed Forces Institute of Pathology (AFIP), 2006. 1v.

JELINEK, F. et al. Medulloepithelioma in a cat. Ceskoslovenska Patologie, v. 32, n. 2, p.75-77, 1996. Available from: $<$ https://www.ncbi.nlm.nih.gov/pubmed/9560905>. Accessed: Jun. 22, 2019.

KLOSTERMAN, E. et al. Immunohistochemical properties of ocular adenomas, adenocarcinomas and medulloepitheliomas. Veterinary Ophthalmology, v.9, n.6, p.387-394, 2006. Available from: <https://onlinelibrary.wiley.com/doi/abs/10.1 111/j.1463-5224.2006.00478.x>. Accessed: Jul. 29, 2019. doi: 10.1111/j.1463-5224.2006.00478.x

KNOTTENBELT, D. C. et al. Primary intraocular primitive neuroectodermal tumor (retinoblastoma) causing unilateral blindness in a gelding. Veterinary Ophthalmology, v.10, n.6, p.348-356, 2007. Available from: <https://pubmed.ncbi.nlm.nih. gov/17970995/>. Accessed: May, 23, 2020. doi: 10.1111/j.14635224.2007.00567.x.

LEIVA, M. et al. Benign intraocular teratoid medulloepithelioma causing glaucoma in an 11-year-old Arabian mare. Veterinary Ophthalmology, v.16, n.4, p.297-302, 2013. Available from: $<$ https://www.researchgate.net/publication/231740575_Benign_ intraocular_teratoid_medulloepithelioma_causing_glaucoma_in an 11-year-old Arabian mare $>$. Accessed: May, 23, 2020. doi: $10.1111 / \mathrm{j} .1463-5224.2012 .01067 . x$.

LOUIS, D. N. et al. The 2007 WHO Classification of tumours of the central nervous system. Acta Neuropathologica, v.114 n.2, p.97-109, 2007. Available from: <https://www.ncbi.nlm.nih. gov/pmc/articles/PMC1929165/\#>. Accessed: Jul. 29, 2019. doi: 10.1007 / s00401-007-0243-4.
MONK, C. S. et al. Clinical behavior of intraocular teratoid medulloepithelioma in two-related Quarter Horses. Veterinary Ophthalmology, v.20, n.6, p.551-559, 2016. Available from: $<$ https://www.ncbi.nlm.nih.gov/pubmed/27440405>. Accessed: Jun. 22, 2019. doi: 10.1111/vop.12409.

POPE, L. Z. B. et al. Meduloepitelioma teratóide maligno do globo ocular: relato de caso e revisão da literatura. Brazilian Journal of Pathology and Laboratory Medicine, Rio de Janeiro, v.38, n.3, 2002. Available from: $<$ http://www.scielo.br/scielo.php?script $=$ sci arttext\&pid=S1676-24442002000300012>. Accessed: Jun. 22, 2019. doi: 10.1590/S1676-24442002000300012.

RIIS, R. C. et al. Intraocular medulloepithelioma in a horse. Equine Veterinary Journal, v.10, p.66-68, 1990. Available from: $<$ https:// onlinelibrary.wiley.com/doi/abs/10.1111/j.2042-3306.1990. tb04715.x>. Accessed: Jun. 22, 2019. doi: 10.1111/j.20423306.1990.tb04715.x.

SCHOENIGER, S. et al. Malignant non-teratoid ocular medulloepithelioma in a Llama (Llama glama). Journal of Veterinary Diagnostic Investigation, v.18, p.499-503, 2006. Available from: <https://pubmed.ncbi.nlm.nih.gov/17037625/>. Accessed: May, 23, 2020. doi: 10.1177/104063870601800517.

SZYMANSKI, C.M. Malignant teratoid medulloepithelioma in a horse. Journal of the American Veterinary Medical Association, v.190, n.3, p.301-302, 1987. Available from: <https://www.ncbi.nlm.nih.gov/pubmed/3558068>. Accessed: Jun. 22, 2019. PMID: 3558068.

UEDA, Y. et al. Ocular medulloepithelioma in a thoroughbred. Equine Veterinary Journal, v.25, p.558-56, 1993. Available from: $\quad<$ https://onlinelibrary.wiley.com/doi/ abs/10.1111/j.2042-3306.1993.tb03017.x>. Accessed: Jun. 22, 2019. doi: 10.1111/j.2042-3306.1993.tb03017.x.

WILCOCK, B; et al. Malignant intraocular medulloepithelioma in a dog. Journal of the American Animal Hospital Association, v.16, p.617-619, 1980. Available from: <http://agris.fao.org/agrissearch/ search.do;jsessionid=122D1AEB7682ECFFDCE5A4F003219129?r equest_locale=ru\&recordID $=$ US19820717968\&query=\&sourceQue ry $=\&$ sortField $=\&$ sortOrder $=$ \&agrovocString $=$ \&advQuery $=$ \&center String=\&enableField $=>$. Accessed: Jun. 22, 2019. ISSN: 0587-2871. 